\title{
Linguagem e memória no construir de futuros professores de inglês
}

Tania Regina de Souza Romero

Universidade de Taubaté

RESUMO: Centramo-nos em uma pesquisa com graduandos de Letras, com o propósito de entender suas concepçôes sobre ensino-aprendizagem e linguagem para posterior ação educativa na Universidade. Implicada nesse objetivo prático, está a discussão do papel da linguagem (VYGOTSKY, 1994; SMOLKA, 2000; ROSSETTI-FERREIRA; AMORIM; SILVA, 2004), narrativa (BRUNER, 2002) e memória (MIDDLETON; BROWN, 2005) na constituição da identidade profissional (VIEIRA, 1999) de futuros professores de inglês. A análise lingüística dos dados é realizada com o apoio instrumental de princípios da Lingüística Sistêmico-Funcional (MARTIN; ROSE, 2003).

PALAVRAS-CHAVE: desenvolvimento de educadores; linguagem; memória; reflexão crítica.

Não vemos as coisas como são, mas como somos. (Anaïs Nin)

\section{O Problema}

A tematização de problemas na formação do professor de línguas estrangeiras tem sido objeto de amplos e candentes debates, a reboque da crise na educação brasileira, conforme se pode rapidamente atestar ao se examinar os últimos programas de eventos que congraçam educadores da área, como a ABRAPUI (Associação Brasileira de Professores Universitários de Inglês) e CBLA (Congresso Brasileiro de Lingüística Aplicada). A questão tem sido abordada, tanto no nível da graduação quanto da pós-graduação, a partir de diversas óticas, dentre as quais figuram investigações nas áreas de processos de reflexão e colaboração, crenças, gêneros textuais, leitura crítica, ideologia, identidades, narrativas, habilidades/competências, currículos, novas tecnologia.

Grandes problemas precisam ser discutidos cuidadosa e urgentemente, em busca das possíveis causas precedendo reformulações. Há necessidade, ademais, que se pondere sobre o alcance e conseqüências sociais e políticas da questão e que se desenvolvam reflexões embasadas, indicando novos caminhos, principalmente quando se trata de práticas tão confortavelmente arraigadas 
como é o caso do ensino de línguas estrangeiras. E quanto mais cedo no processo formativo elas forem trabalhadas, melhor, conforme enfatiza Celani (2000, p.25), "o processo reflexivo relacionado a questóes de linguagem, seu papel e sua construção sociais deve acompanhar a formação do graduando desde o início".

Comprometida com as modificações que se fazem necessárias em meio a conturbados tempos de grandes mudanças sociais, econômicas, culturais, tecnológicas e políticas que presenciamos, e visando intervenção pedagógica para que cenários mais promissores se descortinem, a Universidade de Taubaté, através de seu Programa de Pós-Graduação em Lingüística Aplicada, vem desenvolvendo o projeto Linguagem e Identidade Profissional. Objetiva-se, inicialmente, conhecer como os alunos de Letras concebem ensinoaprendizagem e linguagem para se promover conscientização (BRUNER, 2001; CELANI; MAGALHÂES, 2002; BAILEY et al, 1996; ROMERO, 2004; CASTRO; ROMERO, 2006) e contribuir para possíveis transformações dos futuros profissionais, pois é crucial que estes estejam mais instrumentalizados para atuar nos contextos altamente complexos e multiculturais das escolas contemporâneas (MOITA LOPES, 2003).

Tal iniciativa localiza-se no rastro do pensamento de Freire (1996, p. 36) - "É pensando criticamente a prática de hoje ou ontem que se pode melhorar a próxima prática" - em que o pensar crítico é entendido como aquele que se pauta por interagir dialeticamente com outros paradigmas e outros mundos, objetivando maior compreensão quanto a ideologias, discursos hegemônicos, relações de poder e que, além disso, mobilize o indivíduo para transformações políticas e sociais (BROOKFIELD, 2005).

Tendo como pano de fundo esse panorama, relatamos e discutimos aqui uma das investigações que perfazem o projeto de nossa Universidade, realizada junto a alunas de Letras. Objetivando entender as construções sócio-históricas de graduandas, tomamos como ponto de partida reflexões individuais, elaboradas por escrito por solicitação nossa, sobre o processo de ensinoaprendizagem de língua inglesa, incluindo sentimentos em relação à língua e em relação a professores que participaram na aprendizagem.

Antes de nos atermos à discussão dos dados gerados, faz-se necessário esclarecer o embasamento teórico que orienta a interpretação do estudo. A partir daí, poderão ser tecidas algumas conclusóes, ainda que iniciais, em virtude da magnitude de todo o projeto, indicando possíveis encaminhamentos pedagógicos. 


\section{A lente interpretativa}

Direcionando a lente interpretativa dos dados, articulam-se conceituações sobre linguagem, memória e identidade à luz da perspectiva histórico-cultural. A identidade é entendida em sua natureza dinâmica, resultante de experiências e sentidos construídos social e historicamente pelo indivíduo em interações com outros. Esses sentidos vão tomando forma com a linguagem quando, por exemplo, o ser humano faz uma retrospectiva de suas vivências ao narrar de si, o que, por sua vez, também tem característica marcadamente plástica, uma vez que depende de e adapta-se a contingências contextuais. Dedicamos atenção especial, embora sucinta, considerando os limites dessa discussão, aos conceitos supra-citados para, posteriormente, retornarmos à articulação projetada.

Podemos iniciar a argumentação lembrando que a função óbvia da linguagem é a comunicação. O que interessa, todavia, chamar a atenção para esta conhecida obviedade é a possibilidade que a comunicação implica para a aprendizagem e desenvolvimento, uma vez que é em colaboração com outros, através da interação, que fortemente nos constituímos integrantes de nossa espécie, de nosso nicho social, de nosso posicionamento ante a sociedade. A colaboração inter-pessoal capacita a aprendizagem de quaisquer novas formas de ação cultural, porque, segundo Vygotsky (1987), aprendemos com outros muito além de fatos, mas também mecanismos psicológicos sofisticados tipicamente humanos que se iniciam primeiramente no plano externo (interpsicológico) e posteriormente são internalizados através de um processo de reconstrução pessoal (intra-psicológico). Tem-se, por conseguinte, a transposição de fenômenos sociais para fenômenos psicológicos através da mediação do instrumento linguagem. Ou, conforme pontua Pino (1992), a linguagem, principal instrumento semiótico, realiza a comunicação entre sujeitos e gera a significação no momento mesmo em que ocorre. $\mathrm{O}$ resultado remete a significação como construção social, tecedura conjunta, colaboração gerando aprendizagens.

Este trabalho colaborativo é claramente delineado no conceito vygotskiano de Zona de Desenvolvimento Potencial (ZDP), um dos elementos chave para a compreensão do enfoque sócio-cultural. A aprendizagem, de acordo com este conceito, se dá em um espaço de negociação de significados em que duas ou mais pessoas, diferenciadas assimetricamente por graus distintos de conhecimento, buscam compreender o ponto de vista do outro, explicitando seus próprios, engajando-se, assim, em intensa interação, com o objetivo de construção de novos conhecimentos ou habilidades. Todos os participantes, idealmente, comprometem- 
se a colaborar, seja ensinando o que sabem, da melhor forma que puderem, ou esforçando-se para aprender o que ainda não sabem. Potencialmente, então, e dependendo qualitativamente dos modos de participação (GÓSS, 1994) dos envolvidos, novas formas de funcionamento psíquico surgem. Durante o ciclo de desenvolvimento, realizado no espaço de negociação, há uma dependência daquele(s) participante(s) que está (estão) na posição de aprender, o que se transforma, findo o processo de negociação e tendo ele sido bem sucedido, com a promoção de autonomia em relação à questão trabalhada.

Segundo a perspectiva vygotskiana (VYGOTSKY, 1994), deve-se destacar que além de servir a propósitos comunicativos, a linguagem é para o ser humano o instrumento psicológico responsável pela organização de processos cognitivos, bem como pela própria construção de sentidos que orientam seu olhar e ação no mundo. A linguagem é fundamental ao desenvolvimento das chamadas funções psicológicas superiores, tais como controle consciente do comportamento, memorização ativa, atenção e lembrança voluntária, raciocínio dedutivo, pensamento abstrato, capacidade de planejamento.

Assim, é através da linguagem que nos constituímos tanto como integrantes do grupo humano, social, ideológico em que estamos inseridos, quanto singularizamo-nos, marcando nossos traços individuais. Reforçando a questão, Rossetti-Ferreira, Amorim e Silva (2004) oportunamente destacam que a linguagem tem o poder de transformar a ação, conferindo-lhe estatuto diferenciado, e acrescentam que a indagação não reside apenas em "sobre o que o homem faz com a linguagem como produto de sua atividade, mas o que faz a linguagem, como produção humana, com o próprio homem”. (p. 42).

Voltando a atenção para nossa pesquisa sobre retrospectivas de alunos em formação, deve-se lembrar que é através da linguagem que narramos - e aprendemos a narrar - nossa experiência. E este narrar contribui decisivamente para nos esculpir como seres concomitantemente sociais e individuais, acentua Bruner (2002):

Tenho argumentado que é através da narrativa que criamos e re-criamos o 'eu', que o 'eu' é produto de nosso narrar e não algum tipo de essência a ser sondada nos recessos da subjetividade. Há agora evidência de que se não tivéssemos a capacidade de contar histórias sobre nós mesmos, não haveria o dito 'eu' (p. 84) [tradução nossa]

Continuando, percebe-se a configuração do papel preponderante da linguagem na formação da identidade quando o autor afirma que a capacidade de narrar, possibilitada pela linguagem, também permite tanto unirmo-nos a outros, uma vez que somos primordialmente expressões da cultura que nos 
alimenta, como recortar episódios especialmente significativos de nosso passado para compor nosso "eu" e moldá-lo para as desejadas projeçóes futuras. Além disso, faz questão de salientar que a cultura é dialética e paradoxal, ou, em outras palavras, plena de alternativas, plena de possibilidades de se criar e recriar vários "eus".

Explicitando o entendimento acerca da gênese social da identidade, guiada pelo suporte da linguagem, cabe insistir, com o auxílio de Moita Lopes (2003) que:

(...) o que estou chamando aqui de identidade é um construto de natureza social - portanto político -, isto é, identidade social, compreendida como construída em práticas discursivas, e que não tem nada a ver com a visão de identidade como parte da natureza da pessoa, ou seja, identidade pessoal, nem com sua essência nem com um si-mesmo unitário, ou seja, "tomo como básico não a subjetividade interior do indivíduo, mas os processos sociais ocorrendo entre as pessoas" (Shotter, 1989, p. 137) nos discursos em que estão situadas. (p. 20)

Especificamente no que concerne o profissional educador, Vieira (1999) anteriormente já se posicionava nessa direção, ao afirmar que a identidade é resultante de interações sociais anteriores, que envolvem, além do percurso escolar, igualmente culturas vivenciadas, bem como pessoas significativas que de um modo ou de outro nos marcaram, nos influenciaram, nos fizeram diferentes.

Ao fator sócio-histórico é, portanto, atribuída a identidade profissional, o que permeia a conceituação, por Celani e Magalhães (2002, p. 321), de representaçôes como:

(...) uma cadeia de significações, construídas nas constantes negociações entre os participantes da interação e as significações, as expectativas, as intenções, os valores e as crenças referentes a: (a) teorias do mundo físico; (b) normas, valores e símbolos do mundo social; (c) expectativas do agente sobre si mesmo como ator em um contexto particular.

Concordando, ainda, com esse enfoque, Rossetti-Ferreira, Amorim e Silva (2004) chamam a atenção para a gênese da significação e dos sentidos que brotam do social, são tornados relevantes pelo discurso que, por sua vez, interfere e molda a memória. Ou, nas palavras das autoras:

(...) as possibilidades de significação, de compreensão, de conhecimento, de sentido [ancoram-se] nas práticas sociais, na experiência partilhada (nunca a 'mesma' para todos), como lugar das relaçôes interpessoais que 
vão acontecendo, vão se legitimando e se instituindo; e na 'história' dessas relações, tornada possível pela dimensão discursiva dessas práticas, que implica a memória afetada pelo discurso. (p. 44)

Mas cabe, ainda, acrescentar que a inserção do indivíduo na complexa teia social não é entendida em uma visão determinista, equivocadamente interpretada como sendo a conceituação de habitus de Bourdieu, que conduz mecanicamente agentes sociais segundo sua origem ou condiçôes presentes, pois, de acordo com Nogueira e Nogueira (2004):

(...) embora o habitus seja formado e reflita o universo social no qual o indivíduo foi originalmente socializado, ele não constituiria um conjunto de regras fixas que determinariam, a partir do passado, as açôes atuais do indivíduo. Ao contrário, ele funcionaria como um princípio flexível (um senso de jogo) que permitiria ao indivíduo se adaptar ou mesmo improvisar, dentro de certos limites, diante de cada nova situação. Por outro lado, o conceito nos indicaria, também, que os indivíduos não são completamente determinados pelas condições objetivas presentes no contexto atual da ação. Isso ficaria particularmente claro nos casos em que as condiçóes atuais de ação são muito diferentes daquelas nas quais o indivíduo foi inicialmente socializado. (p. 104)

Tal colocação remete à otimista idéia de transformação social engendrada na visão vygotskiana, sem a qual se torna impossível acreditar no poder da educação. Ao mesmo tempo, exige explicitação sobre o papel do passado, trazido pela memória através da linguagem, no entretecer da identidade do educador ágil que se deseja e se necessita.

Para esclarecer a conceituação de memória que hoje dirige nossa interpretação, é importante referirmo-nos primeiramente ao conceito de "perezhivanie", discutido por Vygotsky, em uma palestra no Izdanie Instituta, Leningrado, e que supostamente se difundiu graças a anotações de M. A. Levina, transcritas e editadas no volume Fundamentos da Pedologia, em 1935.

Assim como mais tarde ecoavam Rossetti-Ferreira, Amorim e Silva (2004), Vygotsky afirma que não são propriamente os fatos ou relações vivenciadas que influenciam nossas características constitucionais, mas a significação que àqueles conferimos. Na perspectiva de Vygotsky (1994), experiências vividas, eventos presenciados ou outros com os quais nos relacionamos, processados através da memória, são refratados através do prisma da experiência emocional [perezhivanie] (p. 340) de cada um. Assim, embora 
a experiência emocional relacione-se a fatores externos, o sentido gerado para a pessoa depende de como ela experiencia eventos, é afetada (ou não), apoiandose em sua compreensão singular, por esses fatores. Decorre, então, que há sempre uma fusão de questôes pessoais e situacionais envolvidas na experiência emocional que contribuem para o desenvolvimento psicológico. Conforme sonoramente diz a professora de yoga "O que o coração não sente, os olhos não vêem” (W. LEITÃO, 2007, comunicação pessoal).

Ressalte-se, entretanto, que - retomando a questão de possível determinismo, conforme colocado acima, que possa ser aventada - a experiência emocional pode ser re-significada, uma vez que tem natureza dinâmica. E tanto significação quanto re-significação são mediadas pela linguagem. Por isso mesmo, Vygotsky sugere a reflexão sobre o conceito do significado das palavras, já que é principalmente através delas que realizamos comunicação psicológica com outros.

Se, então, experiências emocionais, responsáveis por características constitucionais, podem ser constantemente re-significadas através de novas interações sociais, o mesmo ocorre com a memória. Daí Middleton e Brown (2005) entenderem a memória como um construto social que auxilia a autocompreensão, uma vez que seleciona e conecta aspectos de experiências passadas, com o propósito de dar sentido a preocupaçôes e atividades atuais. Continuando a elaboração, nas próprias palavras dos autores:

Quando recordamos o passado, não nos abrimos passivamente a algumas imagens prévias esquecidas, que volta para nós como 'já formada', mas, ao invés disso, remodelamos o passado com base em nossas preocupações e necessidades atuais. Conforme Halbwachs (1992, p. 40) coloca, 'na verdade, o passado não volta como tal... tudo parece indicar que o passado não é preservado, mas é reconstruído com base no presente'. Como acontece essa reconstrução? Aqui, Halbwachs faz sua mais famosa asserção - que a reconstrução é um processo de elaboração mútua entre o indivíduo que se esforça para recordar imagens e o grupo de que ele ou ela é membro. (p. 37) [tradução nossa]

A memória individual, sustentam, é sempre colocada na perspectiva do grupo, o que a torna social. Isso pressupóe uma interdependência do indivíduo e grupo. Logo, tal ótica os leva a afirmar que são "grupos, ao invés dos indivíduos, que de fato 'fazem' a rememoração” (p. 38, tradução nossa). E a intervenção do grupo, bem como a internalização dos sentidos, é realizada na e através da linguagem, pontua Smolka (2000, p. 187): 
Sob os mais diversos pontos de vista, a linguagem é vista como o processo mais fundamental da socialização da memória. A possibilidade de falar das experiências, de trabalhar as lembranças de uma forma discursiva, é também a possibilidade de dar às imagens e recordaçōes embaçadas, confusas, dinâmicas, fluídas, fragmentadas, certa organização e estabilidade. Assim, a linguagem não é apenas instrumental da (re)construção das lembranças; ela é constitutiva da memória, em suas possibilidades e seus limites, em seus múltiplos sentidos, e é fundamental na construção da história.

Considerando o comprometimento do educador com as prementes mudanças sociais, a amálgama dos conceitos acima nos parece de suma relevância, pois que se acentua a necessidade de entender os significados construídos pelos educandos, trazidos pela memória e concretizados na linguagem, para buscar novas re-significações que possam dialogar com o contexto inédito e paradoxal vivido nas escolas atualmente. Justifica-se, deste modo, a tendência, observada nas últimas décadas, do debruçar-se sobre autobiografias para gerar reflexões de natureza fundamentalmente dialética, conforme pontuam Nóvoa e Finger (1988), Magalhães (1994), Bailey et al (1997), Liberali, Magalhães e Romero (2003), Telles (2004), Paiva (2005, 2006), entre outros, bem como as contribuições e a razão de ser deste volume.

Tendo como embasamento as visões acima, voltamo-nos para a questão empírica que exige nossa atenção, especificando abaixo o contexto de pesquisa e o procedimento para análise.

\section{Coleta e Preparo dos Dados}

Pedimos a nossas quinze alunas do terceiro ano de Letras do período matutino que fizeram a opção por licenciatura em inglês/ português (as duas outras opções do curso em nossa Universidade são espanhol/ português e literatura) para que recordassem seu processo de aprendizagem da língua inglesa e também refletissem sobre como hoje vêem este idioma, tomando por base os seguintes pontos: (a) como a língua inglesa se tornou parte de suas vidas, (b) sua relação com a língua inglesa e (c) os professores que tiveram ou têm como referência. Essa contribuição das alunas, que, segundo nossa expectativa, necessariamente as levaria a uma retrospectiva de seu percurso de formação anteriormente e/ou durante a graduação, foi elaborada em casa em português e entregue na semana seguinte, sem a necessidade de identificação, mas todas optaram por se identificar. Selecionamos aqui excertos de seis alunas, usando como critério as respostas mais claras em relação ao foco do estudo. É relevante 
mencionar que as alunas, que aqui aparecem com nomes fictícios para, atendendo a requisitos éticos, terem suas identidades preservadas, tiveram oportunidade de saber e discutir as interpretações desse estudo alguns meses depois, por ocasião de um evento promovido pela própria Universidade.

Os dados obtidos foram categorizados segundo os pontos acima especificados e interpretados teoricamente conforme já discutido. Considerando que significados emergem na e através da linguagem e aí são construídos, buscamos apoio em princípios da lingüística sistêmico-funcional (doravante LSF), uma vez que essa abordagem, vendo na linguagem um sistema para gerar significados, oferece instrumental para análise lingüística que possibilita maior percepção de nossos propósitos.

Para a LSF, a linguagem é parte constitutiva do processo de experiência humana (HALLIDAY, 1994), o que lhe confere natureza essencialmente social. Sendo assim, a linguagem é um sistema de significações que se subjuga a contextos sociais específicos. Através dela emergem significados construídos pelos participantes por meio de um processo de seleção lexical, embora este processo não seja, na grande maioria das vezes, previamente planejado ou consciente. Dito de outra forma, é através do estudo das palavras utilizadas no ato da fala ou escrita, ao longo do entretecer do discurso, que construçóes sóciohistóricas vêem à tona, permitindo, de forma consubstanciada na linguagem, interpretação do pesquisador.

Dentre os vários recursos disponibilizados pela LSF, fizemos uso especialmente da teoria da avaliatividade (appraisal), elaborada por Martin e White (2005). Essa teoria cuida do interpessoal na linguagem, indicando a presença subjetiva do falante ou escritor no texto à medida que este se coloca e avalia tanto as coisas como as pessoas sobre as quais se manifesta. Ao expor lingüisticamente suas posições de valor, que são determinadas socialmente em sua maioria, os falantes ou escritores indicam sua filiação ou distanciamento de comunidades ideológicas.

Martin e White classificam as posições de valor em três grandes grupos: engajamento, gradação e atitude. $\mathrm{O}$ engajamento preocupa-se com o envolvimento e posicionamento tomado diante de coisas e pessoas, ao "investigar os efeitos retóricos associados a esses vários posicionamentos" (MARTIN; WHITE, 2005, p. 92). A gradação atenta para mecanismos lingüísticos utilizados para mostrar alinhamento com maior ou menor intensidade ante ao que é dito ou escrito. A atitude dá conta de sentimentos e envolve áreas semânticas da emoção, ética e estética. Cada uma dessas três 
regióes semânticas é ainda dividida em outras categorias, com o intuito de especificar os significados construídos. Considerando o enfoque de nossa análise, deter-nos-emos em atitude e gradação.

A atitude é desdobrada em três categorias. A categoria de atitude diretamente relacionada a sentimentos é denominada afeto que, por sua vez, pode registrar sensações positivas ou negativas de felicidade, segurança e satisfação. A atitude quanto a questôes éticas, especificamente em relação à avaliação do comportamento de pessoas, é chamada de julgamento. Quando o julgamento geralmente envolve louvor ou condenação com implicaçóes legais, tem-se a sanção social. Se não houver implicação legal, mas o julgamento refletir o que é admirável ou condenável pelo grupo social em que a pessoa em questão está inserida, tem-se a estima social, classificada quanto a capacidade, tenacidade e normalidade. A apreciação, por fim, volta-se para avaliação de coisas, desempenhos ou fenômenos naturais. Suas três sub-categorias podem: (a) remeter a uma reação ante a algo, que pode ser quanto ao impacto que causa ou quanto à qualidade avaliada, (b) referir-se à composição de um texto, peça ou produto, em que se avalia seu equilíbrio ou complexidade, ou (c) expressar outro tipo de avaliação de algo, tal como sua autenticidade, originalidade, criatividade, valor etc.

A gradação indica escalonamento para mais ou para menos, quantificação, intensificação, amplificação ou diminuição de avaliações expressas através das atitudes (ou engajamentos). Ela opera nos eixos da força, em que se revela intensidade e quantidade, e do foco, em que se mostra níveis de precisão ou acuidade.

Embora não seja nosso foco chegar a especificidades da teoria de avaliatividade brevemente explicitada acima, acreditamos que esta incursão nas avaliaçóes expressas, ainda que concisa, contribua para o entendimento da análise que empreendemos com base nas realizações lingüísticas que emergem no discurso das futuras profissionais.

Considerando, então, que objetivamos justamente entender como as futuras professoras se posicionam ante a língua inglesa e avaliam tanto os professores que fizeram parte do processo de aprendizagem quanto o processo em si, o uso do aporte avaliativo da LSF mostra-se adequado. Salientamos, a seguir, alguns significados e posições de valor mais evidentes que os dados revelam, observando especialmente as escolhas lexicais de cada colaboradora na pesquisa. 


\section{Desvendando Significados}

Inicialmente, pensamos em agrupar as contribuições das alunas em três grandes grupos correspondentes aos três aspectos que pretendíamos observar para discussão: (a) como se relacionam com a língua inglesa, (b) como essa língua estrangeira se inseriu em suas vidas e (c) que professor(es) tiveram ou têm como referência no processo de ensino-aprendizagem. Mas percebemos que dois diferentes aspectos - (a) e (b) - se confundiam nos relatos.

A visão geral sobre a inserção do inglês na vida das alunas e como a relação delas com a língua foi percebida e, principalmente, recordada revela-se com nove ocorrências de atitudes de apreciação, seguida de cinco ocorrências de atitudes de afeto, sendo que ambas as atitudes aparecem por vezes intensificadas com gradação de força. Porém, ao focalizar individualmente as avaliações das graduandas, observa-se que os tipos de atitude variam. As alunas Ester e Fátima constroem unicamente atitudes de apreciação de reação, sendo que, enquanto Ester indica um impacto positivo (me dou bem), mostrando como reagiu à inserção do inglês em sua vida, Fátima reage avaliando a qualidade (tem sido bom) da experiência, como se pode observar abaixo:

Ester: Eu me dou bem com inglês, ele começou a fazer parte da minha vida depois que eu fiz um curso e depois passei a lecionar inglês.

Fátima: Falar inglês tem sido bom para mim, pois tenho oportunidade de aprender uma língua nova.

Alice, também utilizando apenas apreciações, refere-se três vezes à composição da experiência: (a) duas vezes aludindo a sua complexidade, o que se percebe com as realizações lingüísticas negativas complicada (que é intensificada com a gradação de força bastante) e dificultou e (b) outra vez mostrando não haver equilíbrio entre o conhecimento que julga necessário para o curso na Universidade e o que possui (não possuía conhecimento prévio em que pudesse me apoiar). Essas avaliações negativas do início da aprendizagem, entretanto, modificam-se, com o uso de uma apreciação de reação denotando qualidade (melhora), reforçada com a gradação significativa.

Bia, por outro lado, traz à tona apenas atitude de afeto, indicando satisfação (gostando), de modo acentuado, com uma gradação de força crescente (cada vez mais):

Bia: Tive um contato maior com o inglês quando comecei a trabalhar em uma escola de idiomas. Depois disso, conforme fui aprendendo, fui gostando cada vez mais. 
As outras duas alunas restantes de nossa amostra, Clara e Diana, fazem emergir atitudes tanto de afeto quanto de apreciação. Clara apresenta indício de afeto, especificamente quanto à satisfação, trazendo a palavra gostei, e faz apreciação de reação, com expressões que denotam seu impacto: curiosidade e querer aprender, sendo que a última expressão é reforçada com a gradação mais.

Clara: Meu primeiro contato com a língua inglesa (na escola) foi na 5a. Série (Escola Estadual). Logo de início, já gostei da matéria. Fiz as três séries seguintes em uma escola Municipal, sendo que, no início da $8^{a}$. série, pedi para minha mãe me matricular em uma escola de línguas, pois eu ouvia músicas em Inglês, cantava em inglês, mas não sabia o que suas letras diziam. Foi essa curiosidade que me levou a querer aprender mais sobre a língua inglesa. Estudei na mesma escola particular (inglês) durante cinco anos (8a. série e 4 anos do Curso Normal). Saí do curso de Inglês quando me matriculei na Unitau, em 2004.

Diana avalia seu processo de aprendizagem com uma apreciação de afeto, demonstrando insatisfação (não me dediquei o suficiente) e continua a apreciação apontando uma composição de desequilíbrio ante ao desejado (sei inglês bem menos do que gostaria). A frustração com o desempenho, todavia, não impede que ela demonstre o afeto positivo em relação à língua (gosto da matéria) e manifeste, com uma apreciação de composição que remete à complexidade, sua capacidade para aprender inglês (não encontro dificuldades).

Diana: Fiz muitos cursos de inglês e parei no ano passado. Desde pequena faço curso. Porém, acredito que não me dediquei o suficiente e sei inglês bem menos do que gostaria. Gosto da matéria e não encontro dificuldades, pelo menos não até o ano passado.

Embora se deva destacar a existência de atitudes diferentes quanto à língua inglesa entre as seis alunas colaboradoras, pode-se inferir que há na maioria uma construção positiva das lembranças do processo de aprendizagem. Exceção é encontrada em excerto de Alice que, iniciando a Universidade e vendo-se aquém dos requisitos básicos, exterioriza o problema enfrentado. Embora a situação pareça se amenizar, o embate se configura, sendo justificado por $o$ fato de não ter feito um curso anterior. A justificativa de Diana pela falta do sucesso desejado, por outro lado, é sinalizada com negativas (menos, não o suficiente) e atribuída a seus próprios esforços: não me dediquei o suficiente, embora saliente seu afeto em Gosto da matéria. As demais alunas usam avaliativos positivos (gostando, gostei, bem, bom). Interessante observar que 
Clara traz essa avaliação positiva como algo que sucedeu instantaneamente, um amor à primeira vista, marcando este significado com realizações temporais (logo de início já gostei), enquanto que Bia condiciona sua adesão a vitórias no processo, fazendo uso de tempos verbais coerentes para com esse significado (conforme fui aprendendo fui gostando) e que se intensificam num crescendo (cada vez mais).

Provavelmente aqui tenhamos indicações de que o processo de aprendizagem de inglês se inicie como algo prazeroso, que seja auxiliado conforme a necessidade de cada um, com indicativos meta-cognitivos para superação de dificuldades e que as conquistas sejam tornadas claras para os alunos para que eles se sintam motivados a prosseguir com os desafios.

Por outro lado, apesar de não estar expresso por meio de avaliativos, observa-se a inclusão - em cinco das seis respostas - do curso particular de idiomas, mesmo quando a instrução dada pela professora-pesquisadora não encaminhasse para isso necessariamente. E justamente por esse motivo essa menção é muito significativa. Poder-se-ia depreender daí que somente se consegue aprender inglês em curso particular de idiomas. Isso, inversamente, apontaria o sentido gerado pela experiência que o inglês ensinado tanto no ensino fundamental e médio, quanto inclusive no ensino superior, não seriam relevantes. Alguns questionamentos preocupantes daí decorrentes poderiam ser: A Universidade apenas testaria e daria o diploma legal necessário? O que se faz nos institutos de idiomas que não se consegue fazer na escola? Por quê? Essas podem ser críticas à nossa atuação como professores e ao sistema que precisam ser priorizadas, com coragem e compromisso para mudança, por mais naturalizadas que sejam, por mais que se entenda como "é assim mesmo que são as coisas em qualquer faculdade". Indo mais adiante, tal significado construído historicamente poderia influenciar na forma como esses futuros professores irão entender sua prática, dependendo do contexto em que atuam? Ou seja, se forem lecionar em escolas de ensino fundamental e médio sentirão que estão menos comprometidos com a aprendizagem de língua inglesa de seus alunos? Essas nos parecem ser questões de grande importância que não podem em hipótese alguma deixar de serem discutidas com os graduandos.

Passando para nossa segunda grande pergunta, quando solicitados a lembrar do professor que hoje lhes serve de referência, tem-se uma representação bem delineada do professor ideal. Das seis alunas, apenas Ester não indicou um educador:

Ester: Não tenho nenhuma referência. 
Como seria de se esperar quando se pede avaliação de pessoas, as demais colaboradoras fizeram emergir atitudes em, principalmente, julgamentos de estima social (onze ocorrências) quanto à capacidade e tenacidade dos professores que recordaram. Todos os julgamentos são de estima social, uma vez que remetem às representaçôes sociais consideradas desejáveis ao professor. Houve um número menor de apreciações (cinco ocorrências) de clima de sala de aula, método, aula e explicação dos professores e apenas uma atitude de afeto, mas relacionado à língua portuguesa, não à inglesa que é nosso objetivo. A gradação apareceu ligada a todos os três tipos de atitude, embora em número reduzido, em comparação à questão anterior.

Fátima e Clara fazem apenas julgamentos quanto à capacidade e tenacidade dos professores recordados:

Fátima: A professora que tenho como referência em inglês é a Sandra. (nome fictício). Ela é dinâmica, paciente e procura atender as $\underline{\text { necessidades do aluno. }}$

Clara: O que mais chama minha atenção com relação aos bons professores do Magistério e da Faculdade é a quantidade de conhecimentos que eles têm relacionados à área em que lecionam. Além disso, durante suas aulas, é possível perceber, por suas falas e ações, $\underline{o}$ prazer que eles sentem em estudar, pesquisar e ensinar.

É interessante verificar que Fátima, além de usar qualificativos de julgamento para a professora Sandra, também descreve suas açôes (procura atender as necessidades dos alunos). Clara, por sua vez, também relaciona o prazer dos professores pelo saber a suas falas e açôes. Tal realização lingüística não somente indica haver, como já discutido por Martin e White (2005), fronteiras pouco claras entre julgamento - feito a pessoas - e apreciação - feita a coisas, produtos e fenômenos naturais (o que justifica diferenças na interpretação de categorias entre analistas), como também pode-se levar a considerar o valor dado pela aluna ao agir do professor na promoção da aprendizagem. Essa construção representada de Clara faz-nos lembrar de Clot que, durante um curso em 2006, na Faculdade de Educação da Universidade Estadual de Campinas, quando chamado a opinar se achava o afeto entre professor e aluno fundamental para a aprendizagem, respondeu, talvez contra as expectativas dos presentes, que $o$ afeto maior não deveria ser entre professor e alunos, mas do professor pelo conhecimento, pela disciplina que leciona, pois que o objetivo da escola é que nos interessemos por algo, não só por pessoas. Parece-nos que a colocação da aluna revela que ela percebeu com seus professores o quanto estudar, pesquisar 
e ensinar pode ser fonte de inquestionável deleite, além de quanto esse deleite tem efeito positivo e construtivamente contagiante.

Alice e Diana constroem a representação do professor modelo com julgamentos e apreciações. Os julgamentos de Alice são: exigente, diferente, o verbo/processo cobrava e na fala de Diana são: dinâmicos, bons e também as descrições de ações apresentam sua matéria em contexto social, cultural et $\mathrm{e}$ estimulam o aluno. Alice faz duas apreciaçóes: uma de composição em relação à complexidade de provas (fáceis) e outra de reação quanto ao impacto do clima de sala de aula (favorável). Diana faz igualmente duas apreciações: uma de reação referindo-se à qualidade da aula (interessante) e outra de reação quanto ao impacto da explicação dos professores (o aluno sente vontade de ler a obra).

Alice: O professor que tenho como referência é minha professora de Português da $8^{a}$. série. Ela sempre foi uma pessoa exigente, mas um tipo de exigência diferente porque cobrava muito durante as aulas e geralmente parecia que as provas eram fáceis. (...) Ela criava um clima favorável e retirava de nós todo o esforço possível.

Diana: Sempre tive meus professores de literatura (tanto do colegial, como da faculdade) como referência em minha vida profissional. Por que eles são dinâmicos e apresentam sua matéria em contexto social, cultural etc. O que torna a aula mais interessante. Com a explicação dos professores sobre as obras literárias o aluno sente vontade de ler a obra. Eles são bons professores, pois estimulam o aluno a querer ler e aprender.

Uma vez mais a importância dada ao agir dos professores é colocada em evidência com o uso de verbos/processos ${ }^{1}$ de ação: cobrava, criava e retirava, para Alice e apresentavam, explicação (uma metáfora gramatical ${ }^{2}$ ) e estimulam para Diana.

Bia, além de fazer uma apreciação de impacto quanto à qualidade do método de ensino (antigo) utilizado por sua professora, também expressa seu afeto (gostasse) em relação à língua portuguesa, acentuando esse afeto com uma gradação (ao ponto de eu querer me tornar professora).

\footnotetext{
${ }^{1} \mathrm{Na}$ perspectiva da Lingüística Sistêmico-Funcional, o grupo verbal é denominado processo (HALLIDAY, 1994). Por limitações de espaço, não trataremos dessa importante parte da teoria neste artigo.

${ }^{2}$ Uma metáfora gramatical, segundo Martin e Rose (2003, p. 103, 104), acontece quando há transferência de significado em que um item lexical, um verbo ou processo, por exemplo, é realizado como coisa. $\mathrm{Na}$ fala acima, explicação (coisa) é a realização do verbo/processo explicar.
} 
Bia: Uma professora que tive na $5^{\mathrm{a}}$., $6^{\mathrm{a}}$., $7^{\mathrm{a}}$. e $8^{\mathrm{a}}$. séries é a minha referência de bom professor, pois, mesmo se utilizando de métodos antigos de ensino, como, por exemplo, chamada oral, fez com que eu aprendesse Português e gostasse ao ponto de eu querer me tornar professora.

O uso de fez com que eu aprendesse, em especial por trazer a força da ação da professora como causadora de aprendizagem, novamente não pode ficar despercebido. Essas ações dos professores, presentes nas falas de cinco graduandas e realizadas lingüisticamente por meio de verbos/processos, parecem sinalizar que parte relevante da representação sobre bons professores vincula-se à responsabilidade pelo sucesso no processo de aprendizagem. Naturalmente, é plausível argumentar que a orientação dada às alunas (professores que tiveram ou têm como referência) possa ter influenciado menção apenas do professor, não dos alunos. ${ }^{3}$ Todavia, nessa frase especificamente (embora as anteriores, de outras graduandas, também sigam essa direção), encontra-se o aluno (eu) como receptor de uma ação que lhe é praticamente forçada ( fez com que) pelo professor que é investido de um poder tal que não só leva a aluna a se transformar cognitiva (aprendesse Português) e afetivamente (gostasse), como também a decidir sobre seu futuro (querer me tornar professora). Ademais, considerando a frase em questão pelo viés da avaliatividade, ela pode ser interpretada como um julgamento de estima social altamente positivo que evidencia capacidade e tenacidade, ou seja, atributos altamente valorizados não só por essa aluna, como tradicionalmente para o professor.

Tal constatação, apesar de não surpreender, ratifica práticas didáticas tradicionais amplamente discutidas e combatidas, mas altamente persistentes e presentes na escola (MIZUKAMI, 1986).

Acompanhando o perfil ideal, seja através de atitudes de julgamento ou de apreciação de ações percebidas em sala de aula, portanto, está a representação que a construção do conhecimento deva ser obra unilateral do professor, ou seja, que a aprendizagem do aluno se dá exclusivamente em resultado da ação do professor, sendo o aluno mero receptor passivo de todo o empenho que ocorre externamente a si próprio. Mesmo sendo esta uma questão óbvia, o que se coloca é se essa elaboração ante o ensinar é a compatível com a esperada pelo futuro docente, em tempos em que o conceito de construção conjunta é

\footnotetext{
${ }^{3}$ Agradeço a contribuição dos pareceristas da Revista pelos importantes comentários que acrescento ao artigo.
} 
amplamente disseminado - como nos Parâmetros Curriculares Nacionais de Língua Estrangeira (BRASIL, 1998), por exemplo, e em praticamente todos os referenciais sobre ação pedagógica.

Indo mais a fundo nas reflexões a que esses dados nos levam, questionamonos quanto ao papel da escola como locus privilegiado para a problematização de construções sócio-históricas sobre a função do professor e do aluno no processo de ensino-aprendizagem, bem como a relação dos futuros profissionais com a área de conhecimento com as quais estão se preparando para trabalhar.

\section{Algumas Indicações (Im)pertinentes}

A nosso ver, a trama de significados que reflete o universo social dos futuros professores de línguas pôde vir à tona mesmo no pequeno corpus com que trabalhamos. Marcas indeléveis como as representações feitas sobre o papel do professor no processo de aprendizagem e o papel da escola de idiomas como o lugar de aprendizagem do inglês não podem ser deixadas de lado no processo de formação do professor. Ficam indicados, assim, caminhos para que nós educadores re-signifiquemos o processo de ensino-aprendizagem de inglês no curso superior. Não podemos nos furtar à constatação de que alguns problemas agudos sobre o fracasso do ensino de inglês na escola, incluindo aí também a Universidade, mais uma vez se expõem, retomando a preocupação de Celani (2003, p. 20):

Mesmo com a restauração das línguas estrangeiras em seu papel formador no currículo da escola fundamental, garantido agora pela Lei de Diretrizes e Bases da Educação Nacional, a situação não parece ter melhorado, visto que as causas têm de ser buscadas em níveis mais profundos de formação inicial de professores de línguas na Universidade.

A oportunidade dada aos alunos para que se expressem, documentem e reflitam sobre sua trajetória é início de um diálogo fundamental, que, concordando novamente com Celani (2000), retomando sua afirmação do início deste artigo, precisa ocorrer intensamente durante a formação. Essa interação, segundo a perspectiva vygotskiana em que nos inserimos, é a essência da Zona de Desenvolvimento Potencial, ou seja, do aprender para atuar crítica e edificantemente na vida. Somente cientes dos sentidos construídos pelos graduandos ao longo de sua trajetória - e as diferenças que há entre eles e suas representaçōes - os educadores têm possibilidade de re-significá-los. Dito de outra forma, o direcionamento para as discussões sobre a prática pedagógica deve originarse nos sentidos esculpidos ao longo do percurso sócio-histórico singular de cada um. 
As discussões cruciais, possibilitadas e realizadas pela linguagem, referindo-nos à postulação de Rossetti-Ferreira, Amorim e Silva (2004), mencionada anteriormente na fundamentação teórica deste artigo, em que é enfatizado o papel preponderante da linguagem na constituição humana, poderão conduzir à transformação dinâmica da ação de aprender e ensinar tanto do educador quanto do graduando, para, esperançosamente, fazer brotar novas identidades profissionais condizentes com a premência evidenciada.

O caminho é árduo, desafiador... Mas, que tal, possível?!

ABSTRACT: Based on research carried out with under-graduate Letters students, we aim at understanding their concepts of learning and teaching, as well as of language in order to plan actions in the University education process. Implied in this practical purpose, this contribution further discusses the role of language (VYGOTSKY, 1994; SMOLKA, 2000; ROSSETTI-FERREIRA; AMORIM; SILVA, 2004), narrative (BRUNER, 2002) and memory (MIDDLETON; BROWN, 2005) in the constitution of professional identity (VIEIRA, 1999) of future teachers of English. The linguistic analysis counts on the instrumental support of Systemic Functional Linguistics principles (MARTIN; ROSE, 2003). KEY-WORDS: educators development; language; memory; critical reflection

\section{Referências Bibliográficas}

BAILEY, K. M. et al. The language learner's autobiography: examining the "apprenticeship of observation". In: FREEMAN, D.; RICHARDS, J. C. (Ed.). Teacher learning in language teaching. Cambridge: Cambridge University Press. 1996. p. 11-29

BRASIL. Secretaria de Educação Fundamental. Parâmetros Curriculares Nacionais: terceiro e quarto ciclos do ensino fundamental: língua estrangeira / Secretaria de Educação Fundamental. Brasília: MEC/SEF, 1998. 120p.

BROOKFIELD, S. D. The power of critical theory: liberating adult learning and teaching. San Francisco: Jossey-Bass, 2005. 414p.

BRUNER, J. A cultura da educação. Porto Alegre: ArtMed. 2001. 186p.

BRUNER, J. Making stories: law, literature, life. Cambridge: Harvard University Press. 2002. 182p.

CASTRO, S. T. R.; ROMERO, T. R. S. A linguagem na formação do educador. In: CASTRO, S, T. R.; SILVA E. R. (Org.). Formação do profissional docente: contribuições de pesquisas em Lingüística Aplicada. Taubaté: Cabral Editora, 2006. p. 125-147. 
CELANI, M.A.A. A relevância da lingüística aplicada na formação de uma política educacional brasileira. In: FORTKAMP, M.B.M.; TOMITCH, L.M.B. (Org.). Aspectos da lingüistica aplicada: estudos em homenagem ao Professor Hilário Bohn. Florianópolis: Insular, 2000. p. 17-32.

CELANI, M.A.A. Professores e formadores em mudança: relato de um processo de reflexão e transformação na prática docente. Campinas: Mercado de Letras. 2003. 223 p.

CELANI, M. A. A.; MAGALHÃES, M. C. C. Representações de professores de inglês como língua estrangeira sobre suas identidades profissionais: uma proposta de reconstrução. In: MOITA LOPES, L. P.; CABRAL BASTOS, L. (Org.). Identidades: recortes multi e interdisciplinares. Campinas: Mercado de Letras, 2002. p. 319-338.

CLOT, Y. "Aspectos da perspectiva histórico-cultural", curso promovido pelo Grupo de Pesquisa Pensamento e Linguagem, Faculdade de Educação, Unicamp, 23 a 25 de maio, 2006.

FREIRE, P. Pedagogia da autonomia: saberes necessários à prática educativa. São Paulo: Paz e Terra. 1996. 148p.

HALLIDAY, M.A.K. An introduction to functional grammar. London: Edward Arnold. 1994. 434p.

GÓES, M.C.R. The modes of participation of others in the functioning of the subject. In: MERCER, N.; COLL, C. (Ed.). Teacher learning and interaction, Madrid: Infancia y Aprendizaje, p. 338-362. 1994.

LIBERALI, F.C.; MAGALHÃES, M.C.C.; ROMERO, T.R.S. Autobiografia, Diário e Sessão Reflexiva: atividades na formação crítico-reflexiva de professores. In: BARBARA, L.; RAMOS, R. C. G. (Ed.). Reflexão e ações no ensinoaprendizagem de linguas. Campinas: Mercado de Letras, p. 131-165. 2003.

MAGALHĀES, M. C. C. Etnografia colaborativa e desenvolvimento de professor. Trabalhos em Lingüistica Aplicada, Campinas, n. 23, p. 71-78, 1994.

MARTIN, J. R.; WHITE, P.R.R. The Language of evaluation: appraisal in English. Basingstoke: Palgrave Macmillan. 2005. 278p.

MARTIN, J.R.; ROSE, D. Working with discourse: meaning beyond the clause. London: Continuum, 2003. 293p.

MIDDLETON, D.; BROWN, S. D. The social psychology of experience: studies in remembering and forgetting. London: Sage Publications. 2005. 252p.

MIZUKAMI, M. G. N. Ensino: as abordagens do processo. São Paulo: EPU, 1986. 119 p. 
MOITA LOPES, L. P. A nova ordem mundial, os parâmetros curriculares nacionais e o ensino de inglês no Brasil: a base intelectual para uma ação política. In: BARBARA, L.; RAMOS, R. C. G. (Org.). Reflexão e ações no ensinoaprendizagem de linguas. Campinas: Mercado de Letras, 2003. p. 29-57.

NOGUEIRA, M. A.; NOGUEIRA, C. M. M. Bourdieu e a educação. Belo Horizonte: Autêntica. 2004. 149p.

NÓVOA, A.; FINGER, M. O método (auto)biográfico e a formação. Odivelas, Portugal: Pentaedro. 1988. 153p.

PAIVA, V. L. M. O. Memórias de aprendizagem de professores de língua inglesa. Contexturas, n. 9, p. 63-78, 2006.

PAIVA, V. L. M. O. Autonomia e complexidade: uma análise de narrativas de aprendizagem. In: FREIRE, M. M.; ABRAHÃO, M. H. V.; BARCELOS, A. M. F. (Org.). Lingüistica aplicada e contemporaneidade. Campinas e São Paulo: Pontes e ALAB, 2005. p. 135-153.

PINO, A. As categorias de público e privado na análise do processo de internalização. Educação \& Sociedade, Campinas, n. 42, p. 245-279, 1992.

ROMERO, T. R. S. Analyzing English teachers' discourse. In: Primera Conferencia Regional Latinoamericana de Lingüística Sistémico-Funcional, Mendoza, Argentina, 2004.

ROSSETTI-FERREIRA, M. C.; AMORIM, K. S.; SILVA, A. P. S. Rede de significações: alguns conceitos básicos. In: ROSSETTI-FERREIRA, M.C.; AMORIM, K. S., SILVA, A. P. S.; CARVALHO, A. M. A. (Org.). Rede de significações e o estudo do desenvolvimento humano. Porto Alegre: ArtMed. 2004. 232 p.

SMOLKA, A. L. B. A memória em questão: uma perspectiva histórico-cultural. Educação e Sociedade, ano XXI, n. 71, p. 166-193, jul. 2000.

TELLES, J. A. Reflexão e identidade profissional do professor de LE: Que histórias contam os futuros professores?. Revista Brasileira de Lingüistica Aplicada, v. 4, n. 2, p. 57-83, 2004.

VIEIRA, R. Histórias de vida e identidades. Porto: Edições Afrontamento. 1999. $397 \mathrm{p}$.

VYGOTSKY, L. S. A formação social da mente. São Paulo: Martins Fontes.1994. $191 \mathrm{p}$.

VYGOTSKY, L. S. The problem of environment. In: VAN DER VEER, R.; VALSINER, J. (Ed.). Vygotsky reader. Oxford: Blackwell, 1994. p. 338-354. 